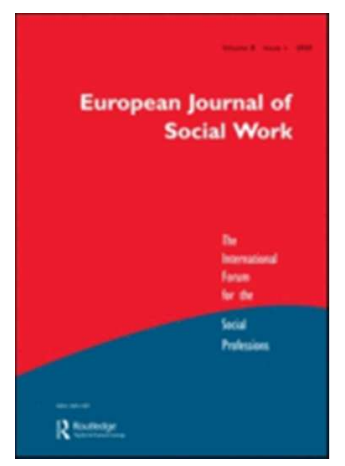

Outreach social work: from managing access to practices of accessibility

\begin{tabular}{|r|l|}
\hline Journal: & The European Journal of Social Work \\
\hline Manuscript ID & CESW-2014-0096.R2 \\
\hline Manuscript Type: & Original Article \\
\hline Keywords: & $\begin{array}{l}\text { Critical perspectives, Human rights/social justice, Care management, Social } \\
\text { policy, Outreaching }\end{array}$ \\
\hline \multicolumn{2}{|l}{} \\
\hline
\end{tabular}

SCHOLARONE

Manuscripts 


\section{Outreach social work: From managing access to practices of accessibility}

\section{Outreachend sociaal werk: van het beheersen van de toegang naar praktijken van toegankelijkheid}

Corresponding Author

Hans Grymonprez

Ghent University

Department of Social Work and Social Pedagogy

Dunantlaan 2

Gent, 9000 (B)

0032468119218

\section{Author 2}

Prof. Dr. Rudi Roose

Ghent University

Department of Social Work and Social Pedagogy

Dunantlaan 2

Gent, 9000 (B)

Author 3

Prof. Dr. Griet Roets

Ghent University

Department of Social Work and Social Pedagogy

Dunantlaan 2

Gent, 9000 (B)

Hans Grymonprez is lecturer social work at the University of Applied Science AP Hogeschool Antwerp (Belgium) and as PhD student attached to the Department of Social Work and Social Pedagogy of Ghent University. Previously he was advocacy worker in Flemish youth work, team coach in a residential youth care facility and mobile social worker in a general welfare work practice.

Rudi Roose is professor in social work affiliated to the Department of Social Work and Social Pedagogy at Ghent University (Belgium). .

Griet Roets is professor in social work affiliated to the Department of Social Work and Social Pedagogy at Ghent University (Belgium). 


\begin{abstract}
A recurring feature of outreach work is that outreach tries to reach people who are left without care and not effectively reached by existing services. In this article, we discuss the importance of outreach practices in the context of changes in society. We suggest that the pressure on the managing of access to social services is increasing along with the demand to avoid an unnecessary inflow, and make a distinction between a residual and structural approach to social work and social service delivery. In a residual approach, outreach social work can be seen as a strategy to manage access or as a strategy to link clients with appropriate services. In this sense, they ensure that people meet predefined criteria of social services. From a structural approach, however, the focus lies on how practices possibly contribute to the realization of human dignity in social interactions and might lead to a socio-political analysis of those situations in which social work intervenes. On a conceptual level, outreach practices thus appear as practices of accessibility. From this perspective, existing problem constructions and dynamics of inclusion and exclusion in social services but also more broadly in society might be questioned and ultimately changed.
\end{abstract}

\title{
Samenvatting:
}

Een terugkerend kenmerk van outreachend werken is dat het mensen probeert te bereiken die door de bestaande hulp- en dienstverlening niet geholpen of bereikt worden. In dit artikel stellen we de betekenis van outreachende praktijken in het sociaal werk ter discussie in het licht van maatschappelijke veranderingen. We stellen dat de druk op het managen van de toegang naar sociale diensten toeneemt samen met de vraag om onnodige instroom te vermijden, en maken een onderscheid tussen een residuele en structurele benadering van het sociaal werk en maatschappelijke dienstverlening. Outreachend werken kan vanuit een residuele benadering gezien worden als een manier om de toegang te bewaken, gericht op het verbinden van de zogenaamd 'juiste' clienten aan de juiste diensten, maar ook zorgen dat mensen voldoen aan voorafgedefinieerde criteria van sociale dienstverlening. Vanuit een structurele benadering gaat de aandacht naar de wijze waarop praktijken een bijdrage kunnen leveren aan de realisatie van menselijke waardigheid in sociale interacties en kunnen leiden tot een sociaal politieke analyse van die situaties waarin sociaal werk tussenkomt.

Conceptueel verschijnen outreachende praktijken daarmee als toegankelijkheidspraktijken. Daarmee kunnen ook de bestaande probleemdefiniëringen van waaruit een aanbod vorm gegeven wordt en de daarmee gepaard gaande dynamieken van in-en uitsluiting in sociale dienstverlening maar ook ruimer in de samenleving in vraag gesteld en veranderd worden.

Keywords: right to social welfare, access, accessibility, outreach social work, structural perspective Trefwoorden: recht op maatschappelijke dienstverlening, toegang, toegankelijkheid, outreachend werken, structureel perspectief 


\section{Introduction}

In the contemporary body of social work research, outreach social work is gaining popularity, as illustrated by the publication of different articles on this topic in various social work and social welfare journals (e.g. Andersson, 2013; Cortis, 2012; Kloppenburg \& Hendriks, 2012; Szeintuch, 2014). Although numerous definitions and descriptions circulate, a point of commonality in these different definitions and descriptions is that outreach practices 'reach out' to target, offer services, engage and bring individuals or groups who are left without care (back) into contact with social support and social services. Outreach practices refer to a certain kind of 'linkage activity’ (Olivet, Bassuk, Elstad, Kenny \& Jessil, 2010; Mikkönen, Kaupinen, Houvinen \& Aalto, 2007; Szeintuch, 2014). As such, outreach social work is seen as an important element in the realisation of welfare rights, through guaranteeing access to these services (Clarke, 2004; Lister, 1998).

In this article, we will argue that outreach social work can function either as a way of 'managing access' or as a 'practice of accessibility'. As a strategy for 'managing' access, we argue that outreach social work practices are deployed as a means to get the right clients in or out of social services, aimed at enhancing more (self-) responsibility and autonomy of clients in order to avoid dependency on social welfare services (e.g. Jordan, 1998). As a practice of accessibility, outreach social work functions as a tool for reflection on dynamics of inclusion and exclusion in social welfare services and society in general. We argue that in the current reforms of social welfare states, the pressure to manage access increases, together with the challenge for outreach practices to maintain their social justice orientation and conceptualise outreach as a spearhead practice in social work.

Our argument is not based on a systematic review, but on a close reading of a diversity of 
prevailing social work literature concerning outreach work, encounters with social work actors in the field of outreach work and policy documents relevant for outreach strategies. The literature available from the Web of Science, with a focus on a diversity of social work literature on outreach work, was selected. A narrative analysis was conducted on topics revealed in this literature. A second source are the first author's experiences in outreach work both in policy and practice in Flanders (e.g. Beelen, Demaeyer, Dewaele, Grymonprez \& Matthijsen, 2014; Grymonprez, Tuteleers \& Kerger, 2014). From this professional role, he held frequent encounters with outreach workers, service managers and local welfare administrators. Other arguments are based on progressive insights wherein social policy in Flanders and the Netherlands picked up outreach strategies as a link between social support and (access to) social services. The conceptual framework we present might enable social work research, policy and practice to gain a more in-depth theoretical understanding of outreach social work and guide future empirical research.

\section{Outreach social work as a linkage activity}

\section{The importance and problem of access to social welfare services}

The idea of access to social services is fundamental in Western societies, and social work has been positioned as having a central role in realising this (Clarke, 2004). According to the global definition of social work (IFSW, 2014), social work is assumed to be a lever in pursuing the agenda of social justice and human rights. Social work, it states, enhances wellbeing, while principles of social justice and collective responsibility are fundamental. Therefore, easy access to provisions and proximity is seen as a guarantee for a more equitable social support (Clarke, 2004; Piessens, 2008). As such, Clarke (2004: 216) postulates: "access is a demand to be treated equitable in relation to a range of valued resources, conditions and relationships". 
Despite these claims, social services remain inaccessible for some groups. It is argued that although social rights are recognised as a political status by society, the welfare rights of these groups of citizens are not realised in practice (Groenez \& Nicaise, 2002; European Commission, 2006). Access to social welfare services was also one of the main themes of the European Year for Combating Poverty and Social Exclusion, and is therefore included in the social policy objectives of European welfare states. This is also reflected in European steered policies in Flanders, as according to the EU 2020 strategy social services should offer "an accessible and affordable quality range of help" in 2020 (Flemish Government, 2010: 11). However, realising access to social welfare services encounters many obstacles (Groenez \& Nicaise, 2002; Boccadoro, 2014). For instance according to prevailing research literature in Flanders, these obstacles occur on the individual, the relational and the structural level (Sannen \& Demeyer, 2003). In general, it is acknowledged that the problem with access can be explained as a phenomenon of social inequalities, which requires the recognition of collective determinants rather than personal misfortune or guilt (Groenez \& Nicaise, 2002; Boccadero, 2014).

\section{Outreach social work as a solution}

A multiplicity of strategies to tackle obstacles in order to improve access are identified and developed. Clarke (2004: 221) states that "access as a policy objective has reshaped the points of engagement between public institutions and society", for instance by changing opening hours, installing new entry points and lower thresholds, or widening eligibility criteria. In general, the will to adapt from the side of social service providers and social workers (e.g. ensuring the help-apparatus to offer optimal services meeting people's needs) is identified as an important feature of social work and as a key determinant for success (Cortis, 2012; Mikkönen et al., 2007). As many people still experience barriers, outreach social work is found to be a suitable way to target underserved populations in their environment. The 
rationale behind these practices is twofold (Mikkönen et al., 2007): on the one hand existing services are not reaching target groups effectively and on the other hand services are not adequately based on the needs of target groups. Outreach social work embodies an "attempt to take a service to people who need it and who would otherwise probably not use services" (Pierson \& Thomas, 1995: 371). As such outreach is identified as a pro-active strategy to target certain individuals (van Doorn, van Etten \& Gademan, 2008). Each attempt should be purposeful to get in touch with targeted groups and should entail structured pathways to connect to social support systems (Andersson, 2013). Different descriptions of these attempts to bring certain individuals or groups into contact with existing (social) services are available in prevalent literature: outreach as an entryway (DeChiara, Unruh, Wolff, Rosen \& Huppert, 2001) or enrolment in social welfare services (Ng \& McQuiston, 2004), as an encouragement of acceptance for referral to the next service (Tsemberis \& Elfenbein, 1999), or as a connection to mainstream services (Erickson \& Page, 1999).

Outreach work is not a single activity (Svensson, 2003; Klose \& Steffan, 1997) but refers to a complex diversity of approaches, traditions and models of establishing contact with certain populations. While 'ideas' of outreach work have been present in social work through history (e.g. the ideas of Chalmers or the practice of friendly visiting at the end of the 19th Century or outreach work targeting drug users or hard to reach HIV patients since the 1980s), practices defined as outreach work are currently widely dispersed in the field of social work (e.g. Szeintuch, 2014). In Flanders for instance, so called outreach teams offer services to the homeless by contacting them on the streets or more hidden places and try, after establishing a trusting relationship, to engage them with low thresholds like nightshelters, residential care centres or other pathways to housing. Another example is the outreach practice 'Xstra' where outreach workers from the public centre of social welfare and the administration of the City of Antwerp knock at the front door after verification that school bills were not paid. The latter is 
believed to be an indication for other problems 'behind the front door' which should be dealt with, starting from an outreach approach.

\section{Outreach social work in a residual welfare state}

\section{Pressure on European welfare states}

Social work cannot distance itself from social, political and historical processes, evolutions and contexts (Lorenz, 2007). As such, the focus of outreach social work on realising access is interrelated with the context and development of the social welfare state. Many European states are currently facing new social and economic risks and are confronted with their own barriers in realising the welfare rights of all their citizens (Biesta, 2011). There is no scientific or political consensus about the future direction of European welfare states and the underlying features and assumptions of social work practices (e.g. Powell \& Hewitt, 2002; TaylorGooby, 1996). Responses to possible future directions are diverse (e.g. Dean, 2012) but can be captured in the balance between a residual and a structural perspective for social work.

\section{From a structural to a residual perspective for social work}

Maeseele (2012) refers, in the context of Belgian homelessness care, to the historically rooted shift from a structural understanding of social welfare to a residual understanding. He defines this shift as threefold: from unconditional welfare rights to conditionality; from an openended finality to instrumentalisation; and from universalism to selectivity. Conditionalities should be understood in terms of a tightened relationship between access to welfare benefits and various responsibilities that individual citizens are obliged to meet (Dwyer, 2004; White, 2000). In that vein, van Oorschot (2006) suggested that the importance of individual responsibility is increasingly stressed while perceptions of deservingness and selfresponsibility give direction to the character of European welfare states. Elchardus and Pelleriaux (2001) identified these processes as associated with new forms of exclusion, new 
forms of inequality, concomitant with increasing precariousness for those with lesser capacity for agency. Instrumentalisation refers to a logic in which targets are defined without taking into account the life world and perspectives of service users as central stakeholders (e.g. labour market participation or law-enforcement). Selectivity refers to the criteria stressing the division between those eligible for social provision and those who are not. This shift also has an impact on perspectives on access to social welfare servies: it implies that access is only for those who are supposed to be in need, for those who meet certain predefined and institutionalised criteria, and for those who are willing or able to be forced to follow certain conditionalities. Hence, access means only the 'right' persons and the 'right' target groups can gain access to social welfare services. In the next section, we will argue how, according to this residual understanding of the welfare state, outreach social work can be installed as a strategy for managing access.

\section{Outreach as a practice of managing access}

\section{A minimalistic approach of the right to social welfare?}

The idea of getting the so-called 'right' persons and target groups in social service delivery positions outreach social work not only as a practice to increase access but also as a practice to prevent those who do not need or deserve access from using social welfare services. An underlying assumption is that if these practices maximize people's strength or reinforce support by and in their own environment, access may be prevented (Farrell, Huff, MacDonald, Middlebro \& Walsh, 2005). In this sense, outreach practices may fit in a minimalistic approach of the right the social welfare (Hubeau, 2009). In this approach welfare rights are limited to a symbolic point of reference; they operate as a functional right, subordinated to the duty to social integration. We will illustrate this evolution with some examples from The Netherlands and Flanders. 
The Dutch 'law on social support' (Wet Maatschappelijke Ondersteuning or WMO) introduced in 2007 and revised in 2015, states that individuals should rely on the community before relying on (public) services. Due to the economic crisis, cuts in spendings seemed unavoidable and the solutions for social problems are increasingly expected to be adressed in the local community. According to the law, accessibility of social services may be desirable but rather secondarily. A way to adress these social problems is based on an outreach approach (Tweede Kamer, 2014), which is seen as a movement from passive 'desk social work' towards a pro-active life-world oriented strategy to strengthen community-supported self-reliance (e.g. Stam, 2012). These principles also underpin the ideology of the 'Big Society' as developed in the United Kingdom; the withdrawal of public responsibility as a guarantee for social rights and an upgraded value to the local community to defeat the consequences of that withdrawal.

Although the transformation of the Belgian welfare state is not as far-reaching as in the Netherlands, the underlying logics in recent policy measures are similar. The Flemish minister of welfare Vandeurzen (2013) made a plea for mobilising societal capital through volunteers and (outreach) social workers for binding formal and informal care networks. His plea already touched ground in mental health care where hospitalisation beds are being replaced by small outreach teams and where outreach teams are expected to prevent hospitalisation ('use of services') by fostering strong communities around their patients. Finally, we also point at the emergence of outreach projects for Eastern European or Northern African homeless people, adressing their problems firstly by the expectation that they rely on their own community but ultimately interventions are also deployed to resettle them in their country of origin.

However, this means that outreach social workers not only work as a 'link' to target, engage and link hard to reach populations to services, but due to changing directions of the welfare state, possibly function as 'gatekeepers'. Gatekeeping is associated with the social 
construction of need of support, the institutionalisation of access to support and the normative direction of goals of support (Walther, 2012). In this sense Steyaert (2014) argued that the redistribution of responsabilities brings along tighter conditions for enrolment into welfare services. Outreach workers then function as so-called 'discretionary allocators' (e.g. Kildal \& Kuhnle, 2002) who should also prevent unneccesary access to social welfare services.

\section{Care-avoiders and problematized service-users}

Nevertheless, this focus on preventing access or fostering independency can engender specific consequences, as it might create the construction of new categories of clients. Welfare recipients who do not or cannot enter social service delivery are problematised when they are perceived by social workers as in need of some kind of intervention. They are sometimes referred to as care avoiders (Elissen, Van Raak, Derckx \& Vrijhoef, 2011) and can be typified as those who are considered as being hard-to-reach (Cortis, 2012). Being considered as hard to reach is a rationale for developing outreach practices (Andersson, 2013). On the other hand, clients whose problems and situations are perceived as too complex to process towards an independent life are also constructed as a problem, which is a frequently recurring argument for welfare reforms. In this context, empirical research conducted in Flemish homelessness care services (Maeseele, 2012) illustrated how social workers in these services point at emerging outreach practices as a possible solution for some homeless people for whom they seem to find no solution towards an independent life.

However, both client constructions are potentially stigmatising, as approaching people in this way ignores the meaning given to the diversity of life situations in which these groups are situated (Moss \& Petrie, 2002). Moreover, as Maeseele (2012) argues, constructions like these define the problem as a problem projected on the group itself rather than as a problem related to in- and exclusionary dynamics of social service delivery. Prior to outreach interventions, 
research (see Andersson, 2013; Carpenter, Luce \& Wooff, 2011) suggests that hard to reach populations have been in contact with social services but developed difficult relationships with them. For instance, Baillergeau (2014) illustrated how people can experience vulnerability and lower self-esteem for interventions based on situations that are comprehended as aberrant. In the same sense Parsell and Parsell (2012) showed how 'homelessness as a choice' is a construction due to the fact that access to affordable housing was not assumed possible or not even an option, especially when the homeless were presumed to be deliberatively homeless. From this perspective, the problem construction of 'hard-toreach' is also revealed as an expression of the ways in which social services are structured and how staff is functioning in this structure (Cortis, 2012). These problem constructions allow institutionalised practices to redefine social problems to recognisable and processable issues (Hjörne, Juhila \& Nijnatten, 2010).

However, it seems unfair to expect from outreach social work to act as a panacea for problems with access if the subsequent services do not meet the needs and concerns of welfare recipients (e.g. Riley, Harding, Underwood \& Carter, 2003). Access by itself doesn't necessarily mean that social services accommodate their work to the concerns of clients. Therefore, we also need to question the underlying logics of social services delivery. Highlighting these questions enables us to shift the focus from characteristics of individuals to the rationale of social services and the way social work perceives these individuals.

Summarising, outreach social work can be seen as a practice in which access can be both promoted and restricted. Against the backdrop of changes in the welfare state, outreach is not only perceived as an instrument to realise the right to social welfare, yet it also may be developed as a way of managing 'excessive' access (e.g. Chevannes, 2002) or dependency on services and thus as an instrument, as part of a minimalistic approach of the right to social welfare, to get the 'right clients' in and the 'wrong clients' out of social service delivery 
(Maeseele, Bouverne-De Bie \& Roose, 2014). From a residual perspective, outreach social work refers to addressing limitations in the ways in which social services function and to the way the most vulnerable individuals fall between the cracks. As such, outreach social work does not necessarily question the possible in- and exclusionary logics and dynamics of social services at hand, but, on the contrary, is also promoted as a solution for these shortcomings. However, this might sustain these possible problematic issues in mainstream social services. In other words, outreach as a 'solution' may be self-referential and refers to 'good' social work that functions within a predefined rationale and conditions of social services and social policy. In that case, not only the route towards social services through outreach is expected to follow a similar fixed and stable path, defined and constructed through these very same social services and social policy (e.g. Gibson, 2011), but also - at least for some- the route out.

\section{Outreach as a practice of accessibility}

\section{Outreach social work from a structural perspective}

However, outreach social work practices are not determined to follow this residual logic. In literature and in practice, we also see outreach practices being developed as a structural policy practice. Where residual policy practices refer to predefined norms or operational criteria of human dignity, leading to managing access, structural policy practices refer to the attempt to realise the right to human flourishing in social interactions (see also Dean, 2010), leading to a social and political analysis of each particular situation in which social work practices potentially intervene. Hence, outreach practices can be seen as practices of accessibility rather than as a tool to manage access. The finality of welfare provisions cannot be reduced to an instrument to support individuals until their needy situation is answered but has its own finality in realising levers to societal change. This implies that social policy and social work might go beyond a residual perspective on social services. We suggest that our conceptual 
analysis of outreach social work primarily as a structural practice and as a maximalistic instead of minimalistic approach of the right to social welfare is worthwile for further elaboration.

\section{A maximalistic approach of the right to social welfare}

From this structural understanding, problem constructions such as 'care avoiders' or 'hard-toreach clients' can lead to a reflection on the way society is organised, to the degree that the question is raised whether social services realise the right to human flourishing for every welfare recipient (Dean, 2013). From this perspective, residual principles like conditionality, instrumentalisation and selectivity may be questioned. This refers to a maximalistic interpretation of the right to social welfare, based on a universal notion of unconditional welfare rights (Dean, 2010) constructed through negotiation in social relationships and grounded in the everyday life world of welfare recipients (Grunwald \& Thiersch, 2009). This implies that social workers embrace the social and political context that sustains the human dignity or right to flourish of welfare recipients (Dean, 2010). This positioning draws attention to the fact that institutions and social organisations are also human constructions and not transcendentally located truths and therefore must be questioned with regard to human dignity or the right to flourish. Following the perspective of social work as a transformative practice, the rationale behind social arrangements, identified as residual welfare ideologies (Rush \& Keenan (2013), i- transformable and should be challenged. This implies also that outreach practices, as a consequence of a structural perspective, are well placed to question how socially just social arrangements can be developed.

\section{Questioning the logic of mainstream and taken-for-granted social work practices}

A structural understanding also refers to outreach social work as a practice that creates democratic space, providing space for debate and conflicting beliefs (Biesta, 2011). The focus 
then shifts from realising access, choice and autonomy towards questioning the complex triangular relationship between the individual, welfare provisions and the state. As such, a political understanding of practices that are dealing in an open-ended way with differences and contradictions is what constitutes a democratic practice. The essence of democracy, argues Biesta (2011), is not about thinking of democracy in terms of a stable order with natural or given borders "but also forecloses the possibility to question how the borders are being drawn and therefore forecloses the possibility for a redrawing of that borders" (2011: 151). However, thinking in terms of managing access assumes stability and order, and may be affirmed in terms of predefined allocation mechanisms and underpinning logics of conditionality, instrumentality and selectivity.

While implementing a structural perspective, outreach social work practices can question the rationale that shapes social work practices, which is utterly a critical and reflexive matter (Adams, Dominelli \& Payne, 2002). A structural perspective implies the necessary reflexivity for discovering or uncovering contradictions in social structures (Fook \& Askeland, 2006; Matthies, 2009). These contradictions are, as Matthies (2009: 321) argues, even deeper in social work since social work is "mainly concerned with people assumed to be powerless and with poorer access to resources". However, a major problem in the development of social work practices and social policy is that target groups are often not heard and their experiences are not taken into account (Krumer-Nevo, 2008).

Rather than managing access, the development of outreach social work as a practice of accessibility cannot be summarised in a concrete definition (Piessens, Lauwers \& Roose, 2008), but the emphasis shifts from the questions of whether, how and under what conditions referrals to social welfare services can be made. This practice of accessibility refers to the 
question of how people can be prevented from access, what the meaning of such practices can be, and how prevailing problem definitions can be questioned. A conceptualisation of accessibility refers to the awareness that the right to social welfare always refers to a commitment to the meaning of 'the right to social welfare' as embodied in real life situations.

\section{Redefining boundaries}

As such 'accessibility' and not mere 'access' appears as a way of questioning basic logics in welfare services, which becomes particularly relevant when individuals are confronted or collide with dynamics and criteria of exclusion, as we have illustrated. Above all, accessibility allows us to cope positively with the ambiguity (Shields, 2006) in which these practices are embedded. Also Maeseele (2012) suggests that accessibility can be understood as a concept to understand how welfare recipients are connected with society and social work. He refers to the construction of practices of accessibility in "which conditions of in- and exclusion are constructed" and are revealed (2012: 124). This connection, he argues, is often based on "conflicting problem definitions and associated questions of power and self-determination" (2012: 56). This might be the case in outreach practices where in- or exclusion processes are made visible, negotiated or imposed. In this sense, Piessens (2008) argued aptly that relying radically on social rights implies an appeal to collective resources and solidarity and is shaped in a public debate about the use of these collective resources. Rather than controlling access, this reframing steers the debate from a debate on management of access towards a reflection on the 'meaning' of access.

It can be argued that we need more empirical research that can provide more insights into the conditions and possibilities of outreach practices as practices of accessibility. For now, we 
would like to discuss some examples to illustrate how outreach practices go beyond thinking in terms of access and are trying to unravel and question dominant logics or problem definitions of social services struggling with access. Morisse, De Neve \& Roets (2014), for instance, refer to the ability and creativity of outreach social workers in the way they question the relationship between the individual, their network, social services and society. Yet they also acknowledge the limitations they have to deal with. Their outreach practice towards people with intellectual disabilities refers to a kind of practice that no longer strives to make itself redundant but acts on "the translation of care and support so that repertoires of action that are experienced as meaningful to all people concerned, are kept open” (Morisse et al., 2014: 38). In the case of needle exchange outreach programmes, for example Stike, O' Grady, Myers \& Millson (2004: 209) revealed that outreachers may "redefine the boundaries of their role and service complements through personal, social, spatial and socio-political forces".

\section{Concluding reflections}

In this article, we stated that in the debate on outreach social work, two different logics might appear: a residual and a structural one which refer to outreach social work as a way of managing access or - what we call - a practice of accessibility. We elaborated arguments that outreach social work should attempt to realise a practice of accessibility rather than embracing or being subjected to the management of access to social services. In contemporary practices, establishing a practice of accessibility might involve ambiguity and floundering. However, we think that outreach social work might make a fundamental contribution to the development of high quality social welfare services, while questioning emerging assumptions and logics in the current welfare state. While conceptually differentiating between a minimalistic and maximalistic realisation of the right to social welfare in social work, we argued that outreach social workers should not loose hope in their struggle to develop structural policy practices. This includes their attempt to realise the right to human flourishing of each welfare recipient, 
leading to a social and political analysis of each particular situation in which social work practices potentially intervene. In this respect an outreach practice might become a 'spearhead practice'. Such spearhead practices are sites of interaction that can raise a better understanding of the character of social welfare and subsequently of how social services and outreach practices themselves deal with their struggle with inclusive and exclusive rationalities. In this sense, outreach social work can initiate an engagement in social services towards the social problems they bring in. Here we refer to the work of Kessl (2009), who imagines a social work that does not comply with given boundaries of the welfare state, since these boundaries are "institutionalized into systematic procedures that affect everyday life" (Beck, Bonns \& Lau, 2003: 20). Acting in terms of practices of accessibility means that outreach social workers are opening up some doors towards a social work "that acts in complex strategic situations as more or less powerful agents" (Kessl, 2009: 315). Gaining insight in specific constructions of accessibility in outreach practices and the broader societal meaning of these interventions is necessary to understand how, in real life practices, high quality of social welfare services can be constructed.

\section{Reference list}

Adams, R., Dominelli, L., \& Payne, M. (2002). Critical Practice in Social Work. Basingstoke: Palgrave.

Andersson, B. (2013). Finding ways to the hard to reach-considerations on the content and concept of outreach work. European Journal of Social Work, 16, 171-186.

Baillergeau, E. (2014). Governing public nuisance: Collaboration and conflict regarding the presence of homeless people in public spaces of Montreal. Critical Social Policy. Retrieved from http://csp.sagepub.com/content/early/2014/03/31/0261018314527716.abstract. doi:10.1177/0261018314527716.

Beelen, S., De Maeyer, J., Dewaele, C., Grymonprez, H. \& Matthijsen, C. (2014). Reach out! Praktijkboek voor Outreachend Werken [Reach out! Handbook for outreach work]. LannooCampus: Tielt. 
Beck, U., Bonss, W., \& Lau, C. (2003). The Theory of Reflexive Modernization: Problematic, Hypotheses and Research Programme. Theory, Culture \& Society, 20(2), 1-33.

Biesta, G. (2011). Learning in Public Places: Civic Learning for the 21st Century. 17th February 2011. Paper presented at the Inaugural Lecture on the Occasion of the Award of the International Francqui Professorship to Prof. Dr. Gert Biesta, 17th February 2011, Ghent.

Boccadoro, N. (2014). Non take-up of minimum income schemes by the homeless population. European Minimum Income Network thematic report. Brussels: European Commission.

Carpenter, J., Luce, A., \& Wooff, D. (2011). Predictors of outcomes of assertive outreach teams: a 3-year follow-up study in North East England. Social Psychiatry and Psychiatric Epidemiology, 46, 463-471.

Chevannes, M. (2002). Social construction of the managerialism of needs assessment by health and social care professionals. Health and Social Care in the Community, 10, 168-178.

Clarke, J. (2004). Access for All? The Promise and Problems of Universalism. Social Work $\&$ Society International Online Journal, 2, 216-224.

Cortis, N. (2012). Overlooked and under-served? Promoting service use and engagement among 'hard-to-reach' populations. International Journal of Social Welfare, 21, 351360 .

Dean, H. (2010). From human needs to social rights: reflections on the responsibility of government. Paper presented at the 4th International Conference on Public Management in The 21st Century: Opportunities and Challenges, Macau (China).

Dean, H. (2012). Welfare Rights and Social Policy. Edinburgh: Pearson Education.

Dean, H. (2013). The translation of needs into rights: reconceptualising social citizenship as a global phenomenon. International Journal of Social Welfare, 22, 32-49. doi: 10.1111/ijsw.12032.

DeChiara, M., Unruh, E., Wolff, T., Rosen, A., \& Huppert, M. (2001). Outreach Works: Strategies for Expanding Health Access in Communities. Gainesville, Florida: AHEC/Community Partners.

Dwyer, P. (2004). Creeping Conditionality in the UK: From Welfare Rights to Conditional Entitlements? Canadian Journal of Sociology, 29, 265-287.

European Commission (2006). Exit from and non-take-up of public services. A comparative analysis: France, Greece, Spain, Germany, Netherlands, Hungaria [EXNOTA]. Final report. European Communities: Luxembourg. 
Elchardus, M., \& Pelleriaux, K. (2001). De nieuwe sociale kwestie. Begripsverduidelijking en discussienota [The new social question. Understanding, clarification and discussion paper]. Brussels: Vakgroep Sociologie - Vrije Universiteit Brussel.

Elissen, A. M. J., Van Raak, A. J. A., Derckx, E. W. C. C., \& Vrijhoef, H. J. M. (2013). Improving homeless persons' utilisation of primary care: lessons to be learned from an outreach programme in The Netherlands. International Journal of Social Welfare, $22(1), 80-89$.

Erickson, S., \& Page, J. (1999). To dance with grace: outreach and engagement to persons on the street Practical Lessons: The 1998 National Symposium on Homeless Research: The 1998 National Symposium on Homeless Research. Washington, DC: US Departments of Housing and Urban Development (HUD) and Health and Human Services (HHS).

Farrell, S. J., Huff, J., MacDonald, S., Middlebro, A., \& Walsh, S. (2005). Taking it to the Street: A Psychiatric Outreach Service in Canada. Community Mental Health Journal, 41, 737-746.

Fook, J. (2002). Social Work: Critical Theory and Practice. London: Sage.

Fook, J., \& Askeland, G. A. (2007). Challenges of Critical Reflection: 'Nothing Ventured, Nothing Gained. Social Work Education, (26)5, 520-533.

Gibson, K. (2011). Homeless Youth, Outreach, and Policing New York's streets. New York University Press: New York.

Groenez, S., \& Nicaise, I. (2002). Traps and springboards in European minimum income systems: The Belgian case. Leuven: HIVA.

Grunwald, K., \& Thiersch, H. (2009). The concept of the 'lifeworld orientation' for social work and social care. Journal of Social Work Practice, 23(2), 131-146.

Grymonprez, H., Kerger, D. \& Tuteleers, P. (2014). Passief en vrijblijvend straathoekwerk : over snoeien met de botte bijl [Passive and non-committal streetwork? [On pruning with a blunt ax]. Alert, tijdscrhrift voor sociaal werk en politiek, 40(2) 24-25.

Hjörne, E., Juhila, K., \& van Nijnatten, C. (2010). Negotiating dilemmas in the practices of street-level welfare work. International Journal of Social Welfare, 19, 303-309.

Hubeau, B. (2009). Op welk welzijnswerk hebben burgers recht? [To which welfare work civilians are entitled?]. Tien mega-trends in (de juridische invulling van) het welzijnswerk en hun gevolgen voor de welzijnsgebruikers. In: K. De Boyser, C. Dewilde, \& D. Dierckx (Eds.), Naar het middelpunt van de marge: reflecties over veertig jaar armoedeonderzoek en -beleid. Leuven/Den Haag: Acco.

IFSW. (2014). Definition of Social Work. Retrieved from http://ifsw.org/policies/definitionof-social-work/ on april, 2, 2015. 
Jordan, B. (1998). The New Politics of Welfare: Social Justice in a Global Context. London: SAGE Publications.

Kessl, F. (2009). Critical reflexivity, social work, and the emerging European post-welfare states. European Journal of Social Work, 12, 305-317.

Kildal, N., \& Kuhnle, S. (2002). The Principle of Universalism: Tracing a Key Idea in the Scandinavian Welfare Model. Paper presented at the Ninth International Congress of Basic Income European Network, Geneva, 12-14 September 2012.

Klose, A., \& Steffan, W. (1997). Streetwork und Mobile Jugendarbeit in Europa. Euroäische streetwork-Explorationstudie. Votum: Münster.

Kloppenburg, R., \& Hendriks, P. (2012). Outreach approaches in the private domain: an international study. European Journal of Social Work, 16(5), 1-15.

Korpi, W., \& Palme, J. (1998). The Paradox of Redistribution and Strategies of Equality: Welfare State Institutions, Inequality, and poverty in the Western Countries. American Sociological Review, 63, 661-687.

Krumer-Nevo, M. (2008). From noise to voice: How social work can benefit from the knowledge of people living in poverty. International Social Work, 51, 556-565.

Lenaerts, G., Roets, G., \& Bouverne-De Bie, M. (2011). Een pad bezaaid met exclusiecriteria [A path strewn with exclusionary criteria]. In K. De Koster, K. De Vos, D. Kerger, G. Roets \& R. Roose (Eds.), Handboek integrale jeugdhulp (Vol. 8, pp. 241-263). Brussels: Politeia.

Lister, R. (1998). From equality to social inclusion: New Labour and the welfare state. Critical Social Policy, 18, 215-225.

Lorenz, W. (2007). Practising history: Memory and contemporary professional practice. International Social Work, 50, 597-612.

Maeseele, T. (2012). From charity to welfare rights? A study of social care practices. Ghent, Belgium: Department of Social Welfare Studies.

Maeseele, T., Bouverne-De Bie, M., \& Roose, R. (2012). On the frontline or on the sideline? Homelessness care and care avoiders. European Journal of Social Work, 16, 620-634.

Matthies, A. (2009). The concept of subjectivisation by Adorno - applied in social work. European Journal of Social Work, 12, 319-332.

Mikkönen, M., Kauppinen, J., Houvinen, M., \& Aalto, E. (2007). Outreach Work among Marginalised Populations in Europe (No. null). Amsterdam: Foundation Regenboog AMOC.

Moss, P., \& Petrie, P. (2002). From Children's Services to Children's Spaces: Public Policy, Children and Childhood. London: Routledge Falmer. 
Morisse, F., De Neve, L., \& Roets, G. (2014). Outreach bij personen met een verstandelijke beperking: bemoeizorg of het betere detectivewerk? [Outreach to people with intellectual disabilities: assertive outreach or better detective work?] In K. De Vos, H. Grymonprez, D. Kerger, G. Roets, R. Roose \& P. Verstraeten (Eds.), Handboek integrale jeugdhulp : cahier outreach (pp. 27-45). Brussels: Politeia.

Ng, A., \& McQuiston, H. (2004). Outreach to the Homeless: Craft, Science, and Future Implications. Journal of Psychiatric Practice, 10(2), 95-105.

Olivet, J. S., Bassuk, E., Elstad, E., Kenney, R., \& Jassil, L. (2010). Outreach and engagement in homeless services: A review of the literature. Open Health Services and Policy Journal, 3, 103-121.

Parsell, C., \& Parsell, M. (2012). Understanding how homelessness is a choice. In Homeless in Europe (pp. 15-16). FEANTSA: Brussels.

Pierson, J., \& Thomas, M. (1995). Collins Dictionary of Social Work. Glasgow: HarperCollins Publishers.

Piessens, A. (2008). De grammatica van het welzijnswerk [The grammar of welfare work]. Ghent: Academia Press.

Piessens, A., Lauwers, L. \& Roose, R. (2008). Onderzoek evaluatie toegankelijkheid integrale jeugdhulp [Research evaluation: accessibility integrated youthcare]. Gent: Vakgroep Sociale Agogiek.

Powell, M., \& Hewitt, M. (2002). Welfare State and Welfare Change. Buckingham: Open University Press.

Riley, A., Harding, G., Underwood, M., \& Carter, Y. (2003). Homelessness: a problem for primary care? British Journal of General Practice, 53, 473-479.

Rush, M., \& Keenan, M. (2013). The Social Politics of Social Work: Anti-Oppressive Social Work Dilemmas in Twenty-First-Century Welfare Regimes. First published online: February 28, 2013. British Journal of Social Work. doi: 10.1093/bjsw/bct014.

Sannen, L., \& Demeyer, B. (2003). Drempels naar welzijnsvoorzieningen: de cliënt aan het woord [Barriers to welfare provisions: the client at word]. Literatuurstudie en diepteinterviews bij kansarmen en etnisch-culturele minderheden. Leuven: KUL/HIVA.

Shields, R. (2006). Boundary-Thinking in Theories of the Present: The Virtuality of Reflexive Modernization. European Journal of Social Theory, 9, 223-237.

Stam, M. (2012). Geef de burger moed. Outreachend werken in tijden van de transformatie van de verzorgingstaat [Encourage the citizen. Outreach social work in times of transformation of the welfare state]. Hogeschool van Amsterdam: Amsterdam.

Steyaert, J. (2014). De meervoudigheid van vermaatschappelijking. De Gids, juni 2014, 11 16. 
Stike, C., O’Grady, C., Myers, T., \& Millson, M. (2004). Pushing the boundaries of outreach work: The case of needle exchange outreach programs in Canada. Social Science \& Medicine, 59(1), 209-219.

Svensson, N. (2003). Outreach work with young people, young drug users and young people at risk. Emphasis on secondary prevention (P-PG/prev (2003) 6E. Pompidou Group with the co-operation of the City of Oslo, Alcohol and Drug Addiction Service Competence Centre. Council Of Europe: Strasbourg.

Szeintuch, S (2014). Street Work and Outreach: A social work Method. British Journal of Social Work [advanced access published October 2014], 1-12. Doi10.1093/bjsw/bcu103.

Taylor-Gooby, P. (1996). The Response of Government: Fragile Convergence? In G. Vic \& P. Taylor-Gooby (Eds.). European Welfare Policy: squaring the welfare circle ( $p p$. 199-218). Macmillan Press: Houndmills.

Tsemberis, S., \& Elfenbein, C. (1999). A perspective on voluntary and involuntary outreach services for the homeless mentally ill. New Directions for Mental Health Services, 82, $9-19$.

Tweede Kamer (2014). Tweede Kamer der Staten-Generaal. Regels inzake de gemeentelijke ondersteuning op het gebied van zelfredzaamheid, participatie, beschermd wonen en opvang (Wet maatschappelijke ondersteuning 2015), Memorie van Toelichting, 33 841 nr. 3. ,Vergaderjaar 2013-2014.

Vandeurzen, J. (2013). De kracht van engagement. Een nieuw welzijnsbegrip [The power of engagement. A new welfare concept]. Retrieved on 3 th of februari from www.jovandeurzen.be.

van Doorn, L. , van Etten, Y., \& Gademan, M. (2008). Outreachend werken, Handboek voor werkers in de eerste lijn. [Outreach work: Handbook for social workers on the frontline]. Bussum: Coutinho.

van Oorschot, W. (2006). Making the difference in social Europe: deservingness perceptions among citizens of European welfare states. Journal of European Social Policy, 16(1), $23-42$.

Flemish Government (2010). Vlaams Actieplan Armoedebestrijding 2010-2014 [Flemish Action Plan for Poverty Reduction 2010-2014]. Brussel: Vlaamse Overheid.

Retrieved 14 june 2014 from http://www4wvg.vlaanderen.be/wvg/armoede/vlaamsactieplan/Documents/VAPA201 0-2014.pdf.

Walters, W. (1997). The 'Active Society': new designs for social policy. Policy \& Politics, $25,221-234$.

Walther, A. (2012). 'Support across life course regimes a comparative model of how social problems, needs and rights are constructed', Paper presented at the 2nd European Conference For Social Work Research, 22nd-24th March, Basel, Switzerland. 
White, S. (2000). Review article: social rights and social contract - political theory and the new welfare politics. British Journal of Political Science, 30, 507-532. 